\title{
EVALUATION OF CARNIOLAN HONEY BEE COLONIES FED ON ARTIFICIAL DIETS UNDER NORTH SINAI CONDITION
}

\author{
Warda F. Ibrahim", H.M. Mahfouz ${ }^{1}$ and M.N.S El-Basiony ${ }^{1}$
}

Dept. Plant Prod., Fac. Environ. Agric. Sci., Arish Univ., Egypt.

\begin{abstract}
The present study was carried out in the farm of the Department of plant Production, Faculty of Environmental Agricultural Sciences, Arish University. This study was carried out to investigate the effect of feeding Carniolan honey bee on different supplementation on venom amounts collected and some biological activities under North Sinai conditions. Results indicated that pollen grains diet significantly $(\mathrm{P} \leq 0.05)$ recorded the highest bee venom weight $(0.1631$ and $0.2106 \mathrm{mg} / \mathrm{col}$.) during the spring season of 2015 and 2016 years, respectively. However, the lowest bee venom weight $(0.0811$ and $0.0692 \mathrm{mg} / \mathrm{col}$.) was observed in the control diets during the spring season of 2015 and 2016 years, respectively. Results indicated that pollen grains diet significantly $(\mathrm{P} \leq 0.05)$ recorded the highest bee venom weight $(0.1724$ and $0.1567 \mathrm{col}$.) during the summer season of 2015 and 2016 years, respectively. Pollen grains diet significantly $(\mathrm{P} \leq 0.05)$ recorded the highest bee venom weight $(0.0924$ and $0.0653 \mathrm{col}$.) during the autumn season of 2015 and 2016 years, respectively. Results revealed pollen grains diet significantly $(\mathrm{P} \leq 0.05)$ recorded the highest bee venom weight $(0.1515$ and $0.1544 \mathrm{mg} / \mathrm{col}$.) during 2015 and 2016 years, respectively compared with other treatments. Results of the interaction between protein nutrition and seasons on bee venom weight indicated that honeybees fed pollen grains diet significantly $(\mathrm{P} \leq 0.05)$ recorded the highest bee venom weight $(0.1515$ and $0.1544 \mathrm{mg} / \mathrm{col}$.) during 2015 and 2016 years, respectively compared with other treatments. Pollen grains diet significantly recorded the highest honey stored area, sealed brood area and pollen stored area (746, 777.5 and 106.3 $\mathrm{inch}^{2} /$ colony) during spring season of 2015 year, respectively and (987.8, 593.6 and 140.8 inch $^{2}$ /colony) in the 2016, respectively. Results revealed that the bee colonies fed pollen grains diet significantly $(\mathrm{P} \leq 0.05)$ recorded the highest honey stored area, sealed brood area and pollen stored area (878.6, 390.4and $123.4 \mathrm{inch}^{2} /$ colony) during summer season of 2015 years, respectively and $\left(1233.73,525.3\right.$ and $118.6 \mathrm{inch}^{2} /$ colony) in the 2016 , respectively. Results indicated that the bee colonies fed pollen grains diet significantly $(\mathrm{P} \leq 0.05)$ recorded the highest honey stored area, sealed brood area and pollen stored area (504.3, 145.8 and $67 \mathrm{inch}^{2} /$ colony) during autumn season of 2015 years, respectively and (825..8, 363.8 and 363.8 inch $^{2} /$ colony) in the 2016, respectively. Results revealed that the bee colonies fed pollen grains diet significantly $(\mathrm{P} \leq 0.05)$ recorded the highest honey stored area, sealed brood area and pollen stored area $(731.4$, 427.7 and $102.5 \mathrm{inch}^{2} /$ colony) in the 2015 years, respectively and (1024.2, 595.2 and 111 $\mathrm{inch}^{2} /$ colony) in the 2016, respectively. The data for the interaction between protein nutrition and seasons biological activities indicated that, the bee colonies fed pollen grains diet in spring, seasons significantly recorded the highest honey stored area, sealed brood area and pollen stored area $\left(746.8,593.6\right.$ and $106.3 \mathrm{inch}^{2} /$ colony) in the 2015 years, respectively and $(987.8,777.5$ and $140.8 \mathrm{inch}^{2} /$ colony) in the 2016 , respectively.
\end{abstract}

Key words: Bee venom, pollen, acacia, barley and artificial diets.

\footnotetext{
* Corresponding author: Tel.: +201288334608

E-mail address: warda.f.zourob@gmail.com
} 


\section{INTRODUCTION}

The honey bee has become tightly linked to human agriculture as one of the most important pollinators. The recent honey bee population decline has raised global concerns of a pollination crisis, yet honey bee research lags far behind in available research tools compared to other model organisms, limiting the pace we can hope to advance our knowledge of honey bee biology and improve bee health. The best known primary products of bee keeping are honey and wax, but pollen, propolis, royal jelly, venom, queen, bees and their larvae are also marketable primary bee products. Bee venom therapy is the part of apitherapy which utilizes bee venom (Nowar, 2016).

Honeybee venom (apitoxin), is a transparent liquid, ornamental pungent smell, a bitter taste, hydrolytic blend of proteins with basic $\mathrm{pH}$ between 4.5 to 5.5 (Ali, 2012). The active portion of apitoxin is a complex mixture of proteins, peptides and low molecular components (Bogdano, 2016) which causes local inflammation and acts as an anticoagulant.

The venom is produced in the abdomen of worker bees from a mixture of acidic and basic secretions. It is synthesized by the venom glands associated with the sting apparatus of worker and queens, stored in the venom reservoir and injected through the sting apparatus during the stinging process. Its production increases during the first two weeks of the adult worker's life and reaches a maximum when the worker bee becomes involved in hive defense and foraging (Roat et al., 2006).

Many factors affecting honey bee venom production and its quality such as; honey bee race, age of bees, colony strength, season of collection, feeding supply, race, its defense behavior and method of collection (Haggag et al., 2015). Besides the painful toxic effects, bee venom has many beneficial biological ones. The most important ones are: anti-inflammatory, antirheumatic, pain-soothing; anti-bacterial; immunosuppressive; radiation-protective; improves hemoglobin synthesis, anticoagulant; accelerates heartbeat, increase blood circulation, lowers blood pressure; lowers cholesterol levels; activates the central nervous system; stimulates building of endogenous cortisone (Ali, 2012). The objectives of this research are studding the effect of honey bee different nutrition treatments on venom amounts collected and some biological activities under North Sinai conditions.

\section{MATERIALS AND METHODS}

The Experiments were carried out at Honeybee Research Unit, Plant Production Department, Faculty of Environmental Agricultural Sciences, Arish University, North Sinai, Egypt during active seasons of 2015 and 2016 on the honey bee Apis mellifera $L$. This study was carried out to study the effect of different types of nutritive protein on some biological activities of honeybee colonies.

\section{Bee Venom Collection}

Bee venom was collected every 30 days for 15 minutes for each colony by using the VCD apparatus according to (Rypak, 1995). Such device was put on top of the hive and the suitable day time for venom collection was in early morning or on sun set to ensure the presence of the most workers in the hives.

\section{Venom Collector Device (VCD) used in the present study}

A new modern VCD apparatus model VC-4FK from Apitronic Canada was used. This apparatus depends on using electrical impulses to stimulate the bee workers to sting through latex sheet places on glass plate to ensure the elimination of contaminants and the prevention of oxidation of the venom in order to obtain pure dry venom. Such venom is white; free 
of contaminations as is known as" Grade I "The dry venom is collected using sharp scraper. The frames of VCD are mounted on top of the hives, then connected to an electro-stimulator. Bees that contact with the wires received a mild electrical shock and stung onto a glass sheet. The alarm odour, which evaporated from the bees glands and mobilized and irritated the other bees to start to sting. At completion of the collection, the VCD is switched off and the bees are shaken off the collector frames. The frames with the fresh dried bee venom on them are carefully packed into a special container and transferred to the laboratory.

\section{Bee Venom Processing in the Laboratory}

The processing of bee venom is starting right after the frames are brought back in the laboratory the venom over the glass plate allowed to dry, in a dark room, in order to prevent the venom oxidation, which may done under light. After this, the powder of venom can be scrapped off the plate; bee venom is packed up in the small dark glass jars and make lyophlization get rid of moisture and stored in a cool and dry place.

Effect of Some Factors on Morphmetrical Characters of Venom Acid Gland

\section{Honeybee Race}

Twenty carniolan race (Apis mellifera carnica) and twenty italian race (Apis mellifera ligustica) honeybee colonies equal in strength were chosen for the experiments (10 honey bee combs housed in Langstroth hives), each treatment consists of 3 colonies.

\section{Honeybee Worker Age on Morphmetrical Measurements}

The experiment was carried out during seasons 2016. Local hybrid Carniolan honeybee workers were used. Three Different ages were used: guard bees, nurse bees.
Honeybee Worker Supply Food on Morphometrical Measurements

Local hybrid Carniolan honeybee workers were used. Twenty honeybee workers (guard bees) were exarnined from nine honeybee colonies at same strength were divided into three groups (was feed on pollen cake, Acacia cake and barley cake, respectively).

\section{Honeybee Samples Collection}

Local hybrid honeybee workers were obtained from Apiaries Faculty of Environmental Agricultural Sciences. Honeybee workers were sampled in summer from hives entrance (guard bees) and kept in $70 \%$ ethyl alcohol for measurements.

Effect of Different Types of Nutritive Protein Diets on the Amount of Collected Bee Venom during Different (Spring, Summer and Autumn) Season of 20152016 Year

Twelfth honey bee colonies from local hybrid carniolan bees equal in strength $(8$ frames covered with bees) were selected and divided in three groups (three coloniesa and one control for each group) as follows:

G1: Experimental colonies were offered weekly 150 grams of acacia cake which prepared: 1 dry bouder of acacia leaves: 1Powder Sugar: I bee honey $(\mathrm{w} / \mathrm{w})$.

G2: Experimental colonies were offered weekly 150 grams of barley bean cake which prepared: 1 barley bean :1 Powder Sugar: 1 bee honey (w/w).

G3: Experimental colonies were offered 50 grams of pollen cake which prepared from 1 pollen grains: 1 bee honey $(\mathrm{w} / \mathrm{w})$.

Beginning of collection the amount of dry bee venom within two years on the same way and the duration is the same period which used in all experiments (15 
minutes) also collected venom after 30 days of treatment.

\section{Biological Activities of Honeybee Colony}

The following biological activities of honeybee colonies were recorded every 12 days intervals for all colonies of honeybee during the different seasons of the year.

1. Average of the colony strength (average of covered combs with bees/colony).

2. Average of worker brood area (inch ${ }^{2} /$ colony).

3. Average of stored honey area (inch ${ }^{2} /$ colony).

4. Average of stored pollen area (inch ${ }^{2}$ colony).

5. Measurement the change of seasonal bee venom production

\section{Statistical analysis}

Data were subjected to statistical analysis by the SAS (2004) computer program using the general linear models (GLM). Significance among treatment means were tested using L.S.D Snedecor and Cochran, (1972).

\section{RESULTS AND DISCUSSION}

Effect of Feeding Supplementation on the Amount of Bee Venom during Deferent Seasons

Carniolan hybrid honey bee colonies were subjected to different nutrition types (control, pollen grains, acacia cake and barley cake). The amount of bee venom was extracted electrically for $15 \mathrm{~min}$ after 10 days from feeding colonies during different seasons (spring, summer and autumn) of 2015/2016 year to study the effect of protein nutrition types in bee venom weight.

\section{Spring Season of 2015/2016 Year}

Data presented in table 1 indicted the quantity of bee venom which was collected from colonies that fed different protein nutrition diets in spring season of the years 2015-2016. Pollen grains diet significantly
$(\mathrm{P} \leq 0.05)$ recorded the highest bee venom weight $(0.1631$ and $0.2106 \mathrm{mg} / \mathrm{col}$.) during the spring season of 2015 and 2016 year, respectively followed with the acacia (0.1128 and $0.1789 \mathrm{mg} / \mathrm{col}$.) during the spring season of 2015 and 2016 year, respectively. The lowest bee venom weight (0.0811 and $0.0692 \mathrm{mg} / \mathrm{col}$.) was observed in the control diets.

The results clearly show that after using pollen grain feeding the amount of dry bee venom increased by $101.10 \%$ in first season 2015 and $204.34 \%$ in second season (2016) as compared with that of venom produced from control .These results are in agreement with (Rashid et al., 2013, Nowar, 2016) they observed decreased in dry bee venom of honeybee workers fed artificially in cages without giving proteins (pollen). This may be due to that pollen supplementary feeding plays an important role in honeybee colony life. Honeybees require many nutrients that found in the diet in a definite quantity for optimum nutrition. Honey bee colonies must be amended with these requirements by the bee keeper (Aly et al., 2014).

\section{Summer Season of 2015/2016 Year}

Data in Table 2 show the effect of protein nutrition on bee venom weight (gm/col.) during summer season. The results reflected the same trend of spring where the highest $(\mathrm{P} \leq 0.05)$ of dry bee venom was recorded $(0.1724$ and $0.1567 \mathrm{gm} / \mathrm{col}$.) with application of pollen feed which producing from honeybees colonies by using electrical impulses device during summer season of 2015 and 2016, respectively compared with the control and other diets.

The data clearly showed that after using pollen grain feeding the amount of dry bee venom increased by $146.28 \%$ in first season (2015) and $173.47 \%$ in second season (2016) as compared with that of venom produced from control. 
SINAI Journal of Applied Sciences (ISSN: 2314-6079) Vol. (6) Is. (3), Dec. 2017

Table (1): The bee venom weight (g/col.) collected from colonies which were fed different diets during spring season of 2015/2016 year.

\begin{tabular}{|c|c|c|c|c|c|c|c|c|}
\hline \multicolumn{9}{|c|}{ Dry bee venom (colony $\backslash 15$ minuts ) } \\
\hline \multicolumn{5}{|c|}{ First Season 2015} & \multicolumn{4}{|c|}{ Second Season 2016} \\
\hline \multirow{2}{*}{$\begin{array}{l}\text { Type of } \\
\text { portentous } \\
\text { food }\end{array}$} & \multicolumn{2}{|c|}{ Range } & \multirow{2}{*}{$\begin{array}{l}\text { Mean } \\
\text { S.E. }\end{array}$} & \multirow{2}{*}{$\begin{array}{c}\text { Rate of } \\
\text { increment } \\
(\%)\end{array}$} & \multicolumn{2}{|c|}{ Range } & \multirow{2}{*}{$\begin{array}{l}\text { Mean } \\
\text { S.E. }\end{array}$} & \multirow{2}{*}{$\begin{array}{c}\text { Rate of } \\
\text { increment } \\
(\%)\end{array}$} \\
\hline & Min. & Max. & & & Min. & Max. & & \\
\hline \multirow{2}{*}{ Control } & \multirow{2}{*}{0.0051} & \multirow{2}{*}{0.2608} & $0.0811 \mathrm{~b}$ & Control & \multirow{2}{*}{0.0090} & \multirow{2}{*}{0.1570} & $0.0692 \mathrm{~b}$ & \multirow{2}{*}{ Control } \\
\hline & & & \pm 0.0277 & & & & \pm 0.0188 & \\
\hline \multirow{2}{*}{ Pollen } & \multirow{2}{*}{0.0888} & \multirow{2}{*}{0.2970} & $0.1631 \mathrm{a}$ & \multirow{2}{*}{$101.10 \%$} & \multirow{2}{*}{0.0925} & \multirow{2}{*}{0.2775} & $0.2106 \mathrm{a}$ & \multirow{2}{*}{$204.34 \%$} \\
\hline & & & \pm 0.0232 & & & & \pm 0.0195 & \\
\hline \multirow{2}{*}{ Acacia } & \multirow{2}{*}{0.0337} & \multirow{2}{*}{0.2151} & $0.1128 \mathrm{ab}$ & & \multirow{2}{*}{0.1040} & \multirow{2}{*}{0.2756} & $0.1789 \mathrm{a}$ & \multirow{2}{*}{$158.52 \%$} \\
\hline & & & \pm 0.0201 & $39.08 \%$ & & & \pm 0.0207 & \\
\hline \multirow{2}{*}{ Barley } & \multirow{2}{*}{0.0339} & \multirow{2}{*}{0.2327} & $0.1071 \mathrm{ab}$ & & \multirow{2}{*}{0.0716} & \multirow{2}{*}{0.2688} & $0.1511 \mathrm{a}$ & \multirow{2}{*}{$118.3 \%$} \\
\hline & & & \pm 0.0293 & $32.05 \%$ & & & \pm 0.0262 & \\
\hline LSD 5\% & \multicolumn{4}{|c|}{0.0731} & \multicolumn{4}{|c|}{0.0621} \\
\hline
\end{tabular}

Table (2): The bee venom weight (g/col.) collected from colonies which were fed different diets during summer season of 2015/2016 year.

\begin{tabular}{|c|c|c|c|c|c|c|c|c|}
\hline \multicolumn{9}{|c|}{ Dry bee venom (colony $\backslash \mathbf{1 5 m i n u t s )}$} \\
\hline \multicolumn{5}{|c|}{ First Season 2015} & \multicolumn{4}{|c|}{ Second Season 2016} \\
\hline \multirow{2}{*}{$\begin{array}{l}\text { Type of } \\
\text { portentous } \\
\text { food }\end{array}$} & \multicolumn{2}{|c|}{ Range } & \multirow{2}{*}{$\begin{array}{c}\text { Mean } \pm \\
\text { S.E. }\end{array}$} & \multirow{2}{*}{$\begin{array}{c}\text { Rate of } \\
\text { increment } \\
(\%)\end{array}$} & \multicolumn{2}{|c|}{ Range } & \multirow{2}{*}{$\begin{array}{c}\text { Mean } \pm \\
\text { S.E. }\end{array}$} & \multirow{2}{*}{$\begin{array}{c}\text { Rate of } \\
\text { increment } \\
(\%)\end{array}$} \\
\hline & Min. & Max. & & & Min. & Max. & & \\
\hline \multirow{2}{*}{ Control } & \multirow{2}{*}{0.0111} & \multirow{2}{*}{0.1584} & $0.0700 \mathrm{~b}$ & \multirow{2}{*}{ Control } & \multirow{2}{*}{0.1719} & \multirow{2}{*}{$\begin{array}{c}0.0135 \\
000\end{array}$} & $0.0573 b$ & \multirow{2}{*}{ Control } \\
\hline & & & \pm 0.0140 & & & & \pm 0.0130 & \\
\hline \multirow{2}{*}{ Pollen } & \multirow{2}{*}{0.0594} & \multirow{2}{*}{0.2963} & $0.1724 \mathrm{a}$ & \multirow{2}{*}{$146.28 \%$} & \multirow{2}{*}{0.0519} & \multirow{2}{*}{0.2616} & $0.1567 \mathrm{a}$ & \multirow{2}{*}{$173.47 \%$} \\
\hline & & & \pm 0.0210 & & & & \pm 0.0191 & \\
\hline \multirow{2}{*}{ Acacia } & \multirow{2}{*}{0.0035} & \multirow{2}{*}{0.1751} & $0.0800 \mathrm{~b}$ & \multirow{2}{*}{$14.28 \%$} & \multirow{2}{*}{0.0109} & \multirow{2}{*}{0.1997} & $0.0980 \mathrm{~b}$ & \multirow{2}{*}{$17.02 \%$} \\
\hline & & & \pm 0.0165 & & & & \pm 0.01968 & \\
\hline \multirow{2}{*}{ Barley } & \multirow{2}{*}{0.0145} & \multirow{2}{*}{0.2850} & $0.1182 \mathrm{ab}$ & \multirow{2}{*}{$68.85 \%$} & \multirow{2}{*}{0.0022} & \multirow{2}{*}{0.1885} & $0.0885 b$ & \multirow{2}{*}{$54.45 \%$} \\
\hline & & & \pm 0.0254 & & & & \pm 0.0196 & \\
\hline LSD 5\% & & & 0.0564 & & & & 0.0516 & \\
\hline
\end{tabular}


According to (Zakaria et al., 2004) feeding worker bees on the tested protein foods particularly bee bread and pollen grains were considered as important factors which affected the quantitative, concentration and venom contents particularly guard bees.

However El-Shearawy et al., (2007) located that the best result was with the pollen grains where it gives the highest bee venom quantity followed with the powder milk then the medical yeast and the sugar solution was at last.

\section{Autumn Season of 2015/2016 Year}

Data in Table 3 show the effect of protein nutrition on bee venom weight ( $\mathrm{gm} / \mathrm{col}$.) during autumn season. The results reflected the same trend of summer where the highest $(\mathrm{P} \leq 0.05)$ of dry bee venom was recorded $(0.0924$ and $0.0653 \mathrm{gm} / \mathrm{col}$.) with application of pollen feed which producing from Carniolan hybrid honeybees colonies by using electrical impulses device during autumn season of 2015 and 2016, respectively compared with the other diets.

The data clearly show that after using pollen grain feeding the amount of dry bee venom increased by $1286.66 \%$ in first season (2015) and 1340.32\% in second season (2016) as compared with that of venom produced from control.

The proteinic food mainly is required for full venom production. Bees fed sugar solution devoid of pollen yielded approximately $23 \%$ of venom produced by bees fed normal pollen diet (Lauter and Vrla, 1939).

Hayes (1984) recommended soybean flour and yeast added to candy as a food to be given to honey bee colonies in the spring. Szymas and Przybyl (1995) investigated how feeding with some pollen substitutes affected different tissues of honey bee. They found that the development of some organs were similar to that of bees that were fed bee bread.
The same authors in their study of efficacy of feeding pollen substitutes to honeybee colonies, found an increase of fat bodies but the pharyngeal glands were developed slightly poorer than in bee bread fed controls. The development of venom gland not examined.

Data presented in Table 4 indicate the quantity of bee venom which was collected from colonies that fed different protein nutrition diets in 2015-2016 years. Pollen grains diet significantly $(\mathrm{P} \leq 0.05)$ recorded the highest bee venom weight $(0.1515$ and $0.1544 \mathrm{mg} / \mathrm{col}$.) during 2015 and 2016 year, respectively compared with other treatments. However the colonies fed control diets achieved the lowest bee venom weight $(0.0592$ and $0.0499 \mathrm{mg} / \mathrm{col}$.) during 2015 and 2016 year, respectively.

The data clearly show that after using pollen grain feeding the amount of dry bee venom increased by $155.91 \%$ in first season 2015 and $209.40 \%$ in second season 2016 as compared with that of venom produced from control. These results are in agreement with (Rashid et al., 2013, Haggag et al., 2015 and Nowar, 2016).

\section{The Interaction between Protein Nutrition and Seasons on Bee Venom Weight}

Results given in Table 5 show the quantity of bee venom which was collected from colonies that fed different protein nutrition diets in different seasons of 20152016 years. The results indicated that honeybees fed pollen grains diet significantly $(\mathrm{P} \leq 0.05)$ recorded the highest bee venom weight $(0.1515$ and 0.1544 $\mathrm{mg} / \mathrm{col}$.) during 2015 and 2016 year, respectively compared with other treatments.

However the colonies fed control diets achieved the lowest bee venom weight (0.0592 and $0.0499 \mathrm{mg} / \mathrm{col}$.) during 2015 and 2016 year, respectively.

These finding is in agreement with (Rashid et al., 2013 and Nowar, 2016). 
SINAI Journal of Applied Sciences (ISSN: 2314-6079) Vol. (6) Is. (3), Dec. 2017

Table (3): The bee venom weight (g/col.) collected from colonies which were fed different diets during autumn season of 2015/2016 year.

\begin{tabular}{|c|c|c|c|c|c|c|c|c|}
\hline \multicolumn{9}{|c|}{ Dry bee venom (g\colony $\backslash 15$ minuts ) } \\
\hline \multicolumn{5}{|c|}{ First Season 2015} & \multicolumn{4}{|c|}{ Second Season 2016} \\
\hline \multirow{2}{*}{$\begin{array}{l}\text { Type of } \\
\text { portentous } \\
\text { food }\end{array}$} & \multicolumn{2}{|c|}{ Range } & \multirow{2}{*}{$\begin{array}{c}\text { Mean } \pm \\
\text { S.E. }\end{array}$} & \multirow{2}{*}{$\begin{array}{c}\text { Rate of } \\
\text { increment } \\
(\%)\end{array}$} & \multicolumn{2}{|c|}{ Range } & \multirow{2}{*}{$\begin{array}{c}\text { Mean } \pm \\
\text { S.E. }\end{array}$} & \multirow{2}{*}{$\begin{array}{c}\text { Rate of } \\
\text { increment } \\
(\%)\end{array}$} \\
\hline & Min. & Max. & & & Min. & Max. & & \\
\hline \multirow{2}{*}{ Control } & \multirow{2}{*}{0.0012} & \multirow{2}{*}{0.0087} & $0.0045 \mathrm{c}$ & \multirow[t]{2}{*}{ Control } & \multirow{2}{*}{0.0007} & \multirow{2}{*}{0.0231} & 0.0062 & \multirow{2}{*}{ Control } \\
\hline & & & \pm 0.0010 & & & & \pm 0.0035 & \\
\hline \multirow{2}{*}{ Pollen } & \multirow{2}{*}{0.0699} & \multirow{2}{*}{0.1160} & $0.0924 \mathrm{a}$ & \multirow{2}{*}{$1286.66 \%$} & \multirow{2}{*}{0.0471} & \multirow{2}{*}{0.0893} & 0.0653 & \multirow{2}{*}{1340.32} \\
\hline & & & \pm 0.0063 & & & & \pm 0.0059 & \\
\hline \multirow{2}{*}{ Acacia } & \multirow{2}{*}{0.0037} & \multirow{2}{*}{0.0956} & $0.0472 b$ & \multirow{2}{*}{$948.88 \%$} & \multirow{2}{*}{0.0009} & \multirow{2}{*}{0.0345} & 0.0120 & \multirow{2}{*}{93.54} \\
\hline & & & \pm 0.0160 & & & & \pm 0.0056 & \\
\hline \multirow[b]{2}{*}{ Barley } & \multirow[b]{2}{*}{0.0119} & \multirow[b]{2}{*}{0.0967} & $0.0489 b$ & \multirow{2}{*}{$986.66 \%$} & \multirow{2}{*}{0.0010} & \multirow{2}{*}{0.0312} & 0.0130 & \multirow{2}{*}{$109 \%$} \\
\hline & & & \pm 0.0115 & & & & \pm 0.0047 & \\
\hline LSD 5\% & & & 0.0307 & & & & 0.015 & \\
\hline
\end{tabular}

Table (4): The bee venom weight (g/col.) collected from colonies which were fed different diets during 2015/2016 year.

\begin{tabular}{|c|c|c|c|c|c|c|c|c|}
\hline \multicolumn{9}{|c|}{ Dry bee venom (g\colony $\backslash 15$ minuts ) } \\
\hline \multicolumn{5}{|c|}{ First Season 2015} & \multicolumn{4}{|c|}{ Second Season 2016} \\
\hline \multirow{2}{*}{$\begin{array}{l}\text { Type of } \\
\text { portentous } \\
\text { food }\end{array}$} & \multicolumn{2}{|c|}{ Range } & \multirow{2}{*}{$\begin{array}{c}\text { Mean } \pm \\
\text { S.E. }\end{array}$} & \multirow{2}{*}{$\begin{array}{c}\text { Rate of } \\
\text { increment } \\
(\%)\end{array}$} & \multicolumn{2}{|c|}{ Range } & \multirow{2}{*}{$\begin{array}{c}\text { Mean } \pm \\
\text { S.E. }\end{array}$} & \multirow{2}{*}{$\begin{array}{c}\text { Rate of } \\
\text { increment } \\
(\%)\end{array}$} \\
\hline & Min. & Max. & & & Min. & Max. & & \\
\hline \multirow{2}{*}{ Control } & \multirow{2}{*}{0.0012} & \multirow{2}{*}{0.2608} & $0.0592 \mathrm{c}$ & \multirow[t]{2}{*}{ Control } & \multirow{2}{*}{0.0007} & \multirow{2}{*}{0.1719} & $0.0499 \mathrm{c}$ & \multirow{2}{*}{ Control } \\
\hline & & & \pm 0.0122 & & & & \pm 0.0095 & \\
\hline \multirow{2}{*}{ Pollen } & \multirow{2}{*}{0.0012} & \multirow{2}{*}{0.2608} & $0.1515 \mathrm{a}$ & \multirow{2}{*}{$155.91 \%$} & \multirow{2}{*}{0.0471} & \multirow{2}{*}{0.2775} & $0.1544 \mathrm{a}$ & \multirow{2}{*}{$209.4 \%$} \\
\hline & & & \pm 0.0134 & & & & \pm 0.0147 & \\
\hline \multirow{2}{*}{ Acacia } & \multirow{2}{*}{0.0035} & \multirow{2}{*}{0.2151} & $0.0837 \mathrm{~b}$ & \multirow{2}{*}{$41.38 \%$} & \multirow{2}{*}{0.0009} & \multirow{2}{*}{0.2756} & $0.1058 \mathrm{~b}$ & \multirow{2}{*}{$112.02 \%$} \\
\hline & & & \pm 0.0112 & & & & \pm 0.0162 & \\
\hline \multirow{2}{*}{ Barley } & \multirow{3}{*}{0.0119} & \multirow{2}{*}{0.2850} & $0.0991 \mathrm{bc}$ & \multirow{2}{*}{$4.09 \%$} & \multirow{2}{*}{0.0010} & \multirow{2}{*}{0.2688} & $0.0926 \mathrm{~b}$ & \multirow{2}{*}{$85.57 \%$} \\
\hline & & & \pm 0.0156 & & & & \pm 0.0155 & \\
\hline LSD 5\% & & & 0.0371 & & & & 0.04 & \\
\hline
\end{tabular}


Table (5): Effect of the interaction between protein nutrition and season on bee venom weight (g/col.) during 2014/2015 year.

\begin{tabular}{|c|c|c|c|}
\hline \multirow{2}{*}{$\begin{array}{c}\text { Type of portentous } \\
\text { food }\end{array}$} & \multirow{2}{*}{ Season } & \multicolumn{2}{|c|}{ Dry bee venom (g\colony $\backslash 15$ minuts) Mean + SE } \\
\hline & & First Season 2015 & Second Season 2016 \\
\hline \multirow{6}{*}{ Control } & \multirow{2}{*}{ Spring } & $0.0811 \mathrm{~b}$ & $0.0692 \mathrm{~cd}$ \\
\hline & & \pm 0.0277 & \pm 0.0188 \\
\hline & \multirow{2}{*}{ Summer } & $0.0700 \mathrm{bc}$ & 0.0573 cde \\
\hline & & \pm 0.0140 & \pm 0.0130 \\
\hline & \multirow{2}{*}{ Autumn } & $0.0045 \mathrm{c}$ & $0.0062 \mathrm{e}$ \\
\hline & & \pm 0.0010 & \pm 0.0035 \\
\hline \multirow{6}{*}{ Pollen } & \multirow{2}{*}{ Spring } & $0.1631 \mathrm{a}$ & $0.2106 \mathrm{a}$ \\
\hline & & \pm 0.0232 & \pm 0.0195 \\
\hline & \multirow{2}{*}{ Summer } & $0.1724 \mathrm{a}$ & $0.1567 \mathrm{a}$ \\
\hline & & \pm 0.0210 & \pm 0.019 \\
\hline & \multirow{2}{*}{ Autumn } & $0.0924 \mathrm{~b}$ & 0.0653 cde \\
\hline & & \pm 0.0063 & \pm 0.0059 \\
\hline \multirow{6}{*}{ Acacia } & \multirow{2}{*}{ Spring } & $0.1128 \mathrm{ab}$ & $0.1789 \mathrm{a}$ \\
\hline & & \pm 0.02018 & \pm 0.0207 \\
\hline & \multirow{2}{*}{ Summer } & $0.0800 \mathrm{~b}$ & $0.0980 \mathrm{bc}$ \\
\hline & & \pm 0.0165 & \pm 0.0196 \\
\hline & \multirow{2}{*}{ Autumn } & $0.0472 \mathrm{bc}$ & $0.0120 \mathrm{de}$ \\
\hline & & \pm 0.0160 & \pm 0.0056 \\
\hline \multirow{6}{*}{ Barley } & \multirow{2}{*}{ Spring } & $0.1071 \mathrm{ab}$ & $0.1511 \mathrm{ab}$ \\
\hline & & \pm 0.0293 & \pm 0.0262 \\
\hline & \multirow{2}{*}{ Summer } & $0.1182 \mathrm{ab}$ & $0.0885 \mathrm{c}$ \\
\hline & & \pm 0.0254 & \pm 0.0196 \\
\hline & \multirow{2}{*}{ Autumn } & $0.0489 \mathrm{bc}$ & $0.0130 \mathrm{de}$ \\
\hline & & \pm 0.0115 & \pm 0.0047 \\
\hline
\end{tabular}




\section{Effect of Feeding Supplementation on the} Biological Activates of Honeybee Colony

\section{Spring season of 2015/2016 year:}

Data in Table 6 showed the effects of protein nutrition types on studies of the biological activities (inch ${ }^{2} /$ colony) in honeybee colonies during spring season of the $2015 / 2016$ years. Results indicated that the bee colonies fed pollen grains diet significantly $(\mathrm{P} \leq 0.05)$ recorded the highest honey stored area, sealed brood area and pollen stored area $(746,593.6$ and 106.3 inch $^{2} /$ colony) in the 2015 year, respectively and (987.8, 777.5 and $140.8 \mathrm{inch}^{2} /$ colony) in the 2016, respectively.

However the bee colonies fed the control diet achieved the lowest honey stored area, sealed brood area and pollen stored area was $\left(296,188.9\right.$ and $57.9 \mathrm{inch}^{2} /$ colony) in the 2015 year, respectively and (468.2, 476.5 and $60.9 \mathrm{inch}^{2} /$ colony) in the 2016 , respectively.

\section{Summer Season of 2015/2016 Year}

Data in Table 7 show the effects of protein nutrition types on studies of the biological activities (inch ${ }^{2} /$ colony) in honeybee colonies during summer season of the 2015/2016 years. Results indicated that the bee colonies fed pollen grains diet significantly $(\mathrm{P} \leq 0.05)$ recorded the highest honey stored area, sealed brood area and pollen stored area $(878.6,390.4$ and 123.4 $\mathrm{inch}^{2} /$ colony) in the 2015 year, respectively and (1233.73, 525.3 and 118.6 inch $^{2} /$ colony) in the 2016, respectively.

However the bee colonies fed the control diet achieved the lowest honey stored area, sealed brood area and pollen stored area (314.4, 121.8 and $33.00 \mathrm{inch}^{2} /$ colony) in the 2015 year, respectively and (568.1, 242.2 and $33.4 \mathrm{inch}^{2} /$ colony) in the 2016 respectively.

\section{Autumn Season of 2015/2016 Year}

Data in Table 8 show the effects of protein nutrition types on studies of the biological activities (inch $2 /$ colony) in honeybee colonies during autumn season of the 2015/2016 years. Results indicated that the bee colonies fed pollen grains diet significantly $(\mathrm{P} \leq 0.05)$ recorded the highest honey stored area, sealed brood area and pollen stored area $(504.3,145.8$ and 67 inch $^{2}$ /colony) in the 2015 year, respectively and $\left(825 . .8,363.8\right.$ and $363.8 \mathrm{inch}^{2} /$ colony) in the 2016 , respectively.

However the bee colonies fed the control diet achieved the lowest honey stored area, sealed brood area and pollen stored area (113.8, 48.9 and 34.8 $\mathrm{inch}^{2} /$ colony) in the 2015 year, respectively and (378.1, 79.1 and $29.7 \mathrm{inch}^{2} /$ colony) in the 2016 , respectively.

Data in Table 9 show the effects of protein nutrition types on studies of the biological activities (inch ${ }^{2} /$ colony) in honeybee colonies during the 2015/2015 years. Results indicated that the bee colonies fed pollen grains diet significantly $(P \leq 0.05)$ recorded the highest honey stored area, sealed brood area and pollen stored area (731.4, 427.7 and $102.5 \mathrm{inch}^{2} /$ colony) in the 2015 year, respectively and (1024.2, 595.2 and $111 \mathrm{inch}^{2} /$ colony) in the 2016, respectively.

However the bee colonies fed the control diet achieved the lowest honey stored area, sealed brood area and pollen stored area (259.6, 135.9 and $44.9 \mathrm{inch}^{2} /$ colony) in the 2015 year, respectively and (476.9, 303.9 and $44.5 \mathrm{inch}^{2} /$ colony) in the 2016, respectively. These results agree with Rashid et al. (2013) who reported that honey bee colonies treated with supplemental diet showed higher activities than colonies with ordinary feeding. 
Table (6): Effect of protein nutrition types on some biological activities during spring season of 2015/2016 year.

\begin{tabular}{ccccccc}
\hline & \multicolumn{5}{c}{ Biological activities (inch ${ }^{2}$ colony) Mean + SE } \\
\hline $\begin{array}{c}\text { Type of } \\
\text { portentous } \\
\text { food }\end{array}$ & \multicolumn{3}{c}{ First Season 2015 } & \multicolumn{3}{c}{ Second Season 2016 } \\
\cline { 2 - 7 } & Honey & Brood & Pollen & Honey & Brood & Pollen \\
& area & area & area & area & area & Area \\
\hline \multirow{2}{*}{ Control } & $296 \mathrm{c}$ & $188.9 \mathrm{c}$ & $57.9 \mathrm{c}$ & $468.2 \mathrm{~d}$ & $476.5 \mathrm{c}$ & $60.9 \mathrm{c}$ \\
& \pm 35.8 & \pm 12.5 & \pm 7.3 & \pm 43.1 & \pm 22.2 & \pm 9.9 \\
& $746 \mathrm{a}$ & $593.6 \mathrm{a}$ & $106.3 \mathrm{a}$ & $987.8 \mathrm{a}$ & $777.5 \mathrm{a}$ & $140.8 \mathrm{a}$ \\
Pollen & \pm 65.7 & \pm 44.3 & \pm 6.5 & \pm 61.1 & \pm 26.2 & \pm 17.2 \\
& $526.3 \mathrm{~b}$ & $356.1 \mathrm{~b}$ & $80.7 \mathrm{~b}$ & $839.8 \mathrm{~b}$ & $537 \mathrm{bc}$ & $81.5 \mathrm{ab}$ \\
Acacia & \pm 51.1 & \pm 20.1 & \pm 8 & \pm 63.7 & \pm 24.8 & \pm 14.6 \\
& $379 \mathrm{c}$ & $421 \mathrm{~b}$ & $56.7 \mathrm{c}$ & $682.4 \mathrm{c}$ & $568.1 \mathrm{~b}$ & $110.3 \mathrm{bc}$ \\
Barley & \pm 41.6 & \pm 35.3 & \pm 5.9 & \pm 37.2 & \pm 17.2 & \pm 22.2 \\
\multirow{2}{*}{ LSD 5\% } & 140.80 & 86.72 & 19.61 & 147.86 & 89.6 & 46.695 \\
\hline
\end{tabular}

Table (7): Effect of protein nutrition types on some biological activities during summer season of 2015/2016 year.

\begin{tabular}{ccccccc}
\hline & \multicolumn{5}{c}{ Biological activities (inch 2 /colony) Mean+SE } \\
\hline $\begin{array}{c}\text { Type of } \\
\text { portentous } \\
\text { food }\end{array}$ & \multicolumn{3}{c}{ First Season 2015 } & \multicolumn{3}{c}{ Second Season 2016 } \\
\cline { 2 - 7 } & Honey & Brood & Pollen & Honey & Brood & Pollen \\
& area & area & area & area & area & area \\
\hline \multirow{2}{*}{ Control } & $314.4 \mathrm{c}$ & $121.8 \mathrm{~b}$ & $33.00 \mathrm{c}$ & $568.1 \mathrm{c}$ & $242.2 \mathrm{~b}$ & $33.4 \mathrm{~b}$ \\
& \pm 37.2 & \pm 16 & \pm 13.1 & \pm 28.2 & \pm 28.7 & \pm 6.2 \\
& $878.6 \mathrm{a}$ & $390.4 \mathrm{a}$ & $123.4 \mathrm{a}$ & $1233.73 \mathrm{a}$ & $525.3 \mathrm{a}$ & $118.6 \mathrm{a}$ \\
Pollen & \pm 28.2 & \pm 32.6 & \pm 7.2 & \pm 13.4 & \pm 62.7 & \pm 24 \\
& $513.6 \mathrm{~b}$ & $153.5 \mathrm{~b}$ & $46.7 \mathrm{bc}$ & $1159.67 \mathrm{a}$ & $515.7 \mathrm{a}$ & $58.00 \mathrm{ab}$ \\
Acacia & \pm 14.7 & \pm 14.1 & \pm 5.6 & \pm 21.9 & \pm 37.1 & \pm 13.8 \\
& $455.7 \mathrm{~b}$ & $137.2 \mathrm{~b}$ & $69.8 \mathrm{~b}$ & $819.8 \mathrm{~b}$ & $452.8 \mathrm{a}$ & $111.5 \mathrm{a}$ \\
Barley & \pm 36.1 & \pm 15.9 & \pm 15.2 & \pm 40.3 & \pm 53.8 & \pm 32.4 \\
LSD 5\% & 86.83 & 59.96 & 31.38 & 78.60 & 134.61 & 61.04 \\
\hline
\end{tabular}


SINAI Journal of Applied Sciences (ISSN: 2314-6079) Vol. (6) Is. (3), Dec. 2017

Table (8): Effect of protein nutrition types on some biological activities during autumn season of 2015/2016 year.

\begin{tabular}{ccccccc}
\hline & \multicolumn{5}{c}{ Biological activities (inch ${ }^{2}$ /colony) Mean+SE } \\
\hline $\begin{array}{c}\text { Types of } \\
\text { portentous } \\
\text { food }\end{array}$ & \multicolumn{3}{c}{ First Season 2015 } & \multicolumn{3}{c}{ Second Season 2016 } \\
\cline { 2 - 7 } & Honey & Brood & Pollen & Honey & Brood & Pollen \\
& area & area & area & area & area & area \\
\hline \multirow{2}{*}{ Control } & $113.8 \mathrm{c}$ & $48.9 \mathrm{c}$ & $34.8 \mathrm{~b}$ & $378.1 \mathrm{c}$ & $79.1 \mathrm{c}$ & $29.7 \mathrm{~b}$ \\
& \pm 15.1 & \pm 10.7 & \pm 11.3 & \pm 37.1 & \pm 9.1 & \pm 8.1 \\
\multirow{2}{*}{ Pollen } & $504.3 \mathrm{a}$ & $145.8 \mathrm{a}$ & $67 \mathrm{a}$ & $825.8 \mathrm{a}$ & $363.8 \mathrm{a}$ & $363.8 \mathrm{a}$ \\
& \pm 74 & \pm 18.8 & \pm 2.2 & \pm 64.8 & \pm 40.3 & \pm 40.3 \\
\multirow{2}{*}{ Acacia } & $334.9 \mathrm{~b}$ & $86.9 \mathrm{~b}$ & $41.6 \mathrm{~b}$ & $703.1 \mathrm{a}$ & $161.6 \mathrm{~b}$ & $70.8 \mathrm{ab}$ \\
& \pm 50.7 & \pm 12.9 & \pm 3.5 & \pm 44.7 & \pm 18.2 & \pm 22.9 \\
\multirow{2}{*}{ Barley } & $233.2 \mathrm{bc}$ & $69.3 \mathrm{bc}$ & $42.7 \mathrm{~b}$ & $515 \mathrm{~b}$ & $188.7 \mathrm{~b}$ & $36.3 \mathrm{ab}$ \\
& \pm 36.8 & \pm 7.5 & \pm 1.8 & \pm 40.1 & \pm 17.9 & \pm 7.4 \\
LSD 5\% & 141.35 & 37.94 & 17.53 & 136.65 & 69.30 & 38.78 \\
\hline
\end{tabular}

Table (9): Effect of protein nutrition types on some biological activities during 2015/2016 year.

\begin{tabular}{ccccccc}
\hline \multicolumn{5}{c}{ Biological Activities (inch ${ }^{2} /$ colony) Mean+SE } \\
\hline $\begin{array}{c}\text { Type of } \\
\text { portentous } \\
\text { food }\end{array}$ & \multicolumn{7}{c}{ First Season 2015 } & \multicolumn{3}{c}{ Second Season 2016 } \\
\cline { 2 - 7 } & $\begin{array}{c}\text { Honey } \\
\text { area }\end{array}$ & $\begin{array}{c}\text { Brood } \\
\text { area }\end{array}$ & $\begin{array}{c}\text { Pollen } \\
\text { area }\end{array}$ & $\begin{array}{c}\text { Honey } \\
\text { area }\end{array}$ & $\begin{array}{c}\text { Brood } \\
\text { area }\end{array}$ & $\begin{array}{c}\text { Pollen } \\
\text { area }\end{array}$ \\
\hline \multirow{2}{*}{ Control } & $259.6 \mathrm{~d}$ & $135.9 \mathrm{c}$ & $44.9 \mathrm{c}$ & $476.9 \mathrm{~d}$ & $303.9 \mathrm{c}$ & $44.5 \mathrm{c}$ \\
& \pm 23.9 & \pm 11.9 & \pm 6 & \pm 24.7 & \pm 27.2 & \pm 5.5 \\
\multirow{2}{*}{ Pollen } & $731.4 \mathrm{a}$ & $427.7 \mathrm{a}$ & $102.5 \mathrm{a}$ & $1024.2 \mathrm{a}$ & $595.2 \mathrm{a}$ & $111 \mathrm{a}$ \\
& \pm 41.5 & \pm 36.7 & \pm 4.9 & \pm 38.3 & \pm 34.9 & \pm 11.9 \\
Acacia & $478.3 \mathrm{~b}$ & $231.7 \mathrm{~b}$ & $61.2 \mathrm{~b}$ & $905.6 \mathrm{~b}$ & $436.5 \mathrm{~b}$ & $71.5 \mathrm{bc}$ \\
& \pm 29.1 & \pm 21.8 & \pm 5 & \pm 40.1 & \pm 28.2 & \pm 9.4 \\
\multirow{2}{*}{ Barley } & $368.9 \mathrm{c}$ & $252.5 \mathrm{~b}$ & $57.5 \mathrm{bc}$ & $683.5 \mathrm{c}$ & $437.2 \mathrm{~b}$ & $92.1 \mathrm{ab}$ \\
\multirow{2}{*}{ LSD 5\% } & \pm 26.7 & \pm 30.7 & \pm 5.5 & \pm 27.9 & \pm 28.8 & \pm 14.6 \\
\hline
\end{tabular}


Effect of Interaction between Protein Nutrition and Seasons Biological Activities

Data in Table 10 show the effects of interaction between protein nutrition types and seasons on studies of the biological activities (inch ${ }^{2} /$ colony) in honeybee colonies during the 2015/2016 years. Results indicated that the bee colonies fed pollen grains diet in spring season significantly $(\mathrm{P} \leq 0.05)$ recorded the highest honey stored area, sealed brood area and pollen stored area (746.8, 593.6 and 106.3 inch $^{2} /$ colony) in the 2015 year, respectively and (987.8, 777.5 and $140.8 \mathrm{inch}^{2} /$ colony) in the 2016 , respectively.

\section{Effect of Honeybee Worker Food Diets on Morphometrical Measurements}

Data in Figure 1 show that honey bee fed on pollen significantly $(\mathrm{P} \leq 0.05)$ had the highest total gland length, poison sac length (9.711, 2.046 and $0.816 \mathrm{~mm}$, respectively) compared with those fed on acacia (9.288, 1.959 and 0.756$)$ and barley $(9.123,1.968$ and $0.711 \mathrm{~mm}$ ).

Table (10): Effect of the interaction between protein nutrition and seasons on some biological activities.

\begin{tabular}{|c|c|c|c|c|c|c|c|}
\hline \multirow[b]{3}{*}{ Diet } & \multirow{4}{*}{ Season } & \multicolumn{6}{|c|}{ Biological activities (inch²/colony) Mean+SE } \\
\hline & & \multicolumn{3}{|c|}{ First Season 2015} & \multicolumn{3}{|c|}{ Second Season 2016} \\
\hline & & Honey & Brood & Pollen & Honey & Brood & Pollen \\
\hline Type & & area & area & area & area & area & area \\
\hline \multirow[t]{3}{*}{ Control } & Spring & $296 \mathrm{~d} \pm 35.8$ & $188.9 \mathrm{c} \pm 12.4$ & 57.9 bcde \pm 7.2 & 468.2gf \pm 43.1 & $476.5 \mathrm{~b} \pm 22.2$ & $60.9 \mathrm{~cd} \pm 9.9$ \\
\hline & Summer & $314.4 \mathrm{~cd} \pm 37.2$ & $121.7 \mathrm{cde} \pm 16$ & $33 \mathrm{e} \pm 13.1$ & $568.1 \mathrm{ef} \pm 28.2$ & $242.2 \mathrm{e} \pm 8.6$ & $33.4 \mathrm{~d} \pm 6.2$ \\
\hline & Autumn & $113.8 \mathrm{e} \pm 15.1$ & $48.9 \mathrm{e} \pm 10.7$ & $34.7 \mathrm{e} \pm 11.3$ & $378.1 \mathrm{~g} \pm 37.1$ & $79.1 \mathrm{f} \pm 9.1$ & $29.7 d \pm 8.1$ \\
\hline \multirow[t]{3}{*}{ Pollen } & Spring & $746.8 \mathrm{a} \pm 65.8$ & 593.6 a \pm 44.3 & $106.3 \mathrm{a} \pm 6.5$ & $987.8 b \pm 61.1$ & $777.5 \mathrm{a} \pm 26.2$ & $140.8 \mathrm{a} \pm 17.2$ \\
\hline & Summer & $878.6 a \pm 28.2$ & $390.4 b \pm 32.6$ & $123.4 a \pm 7.2$ & $1233.7 \mathrm{a} \pm 13.4$ & $525.3 b c \pm 62.6$ & $118.6 \mathrm{ab} \pm 24$ \\
\hline & Autumn & $504.3 b \pm 74$ & $145.8 \mathrm{~cd} \pm 18.9$ & $67 \mathrm{bcd} \pm 2.2$ & $64.8 \mathrm{~cd} \pm 825.8$ & $40.3 \mathrm{~d} \pm 363.8$ & $49.4 d \pm 9.8$ \\
\hline \multirow[t]{3}{*}{ Acacia } & Spring & $526.4 \pm 51.1 b$ & $356.1 \mathrm{~b} \pm 20.1$ & $80.7 b \pm 8$ & $839.8 \mathrm{c} \pm 63.7$ & $537 b c \pm 24.7$ & $81.5 \mathrm{~cd} \pm 14.6$ \\
\hline & Summer & $513.7 b \pm 14.8$ & $153.6 \mathrm{~cd} \pm 14$ & 46.7 cde \pm 5.6 & $159.6 a \pm 21.9$ & $515.7 b c \pm 37.1$ & $58 \mathrm{~cd} \pm 13.7$ \\
\hline & Autumn & $334.9 \mathrm{~cd} \pm 50.6$ & $86.9 \mathrm{de} \pm 12.9$ & $41.5 \mathrm{ed} \pm 3.5$ & 703.2 cde \pm 44.7 & 161.7 ef \pm 18.2 & $70.8 \mathrm{bcd} \pm 22.8$ \\
\hline \multirow[t]{3}{*}{ Barley } & Spring & 379 bcd \pm 41.6 & $421 \mathrm{~b} \pm 35.3$ & 56.7 bcde \pm 5.8 & $515 \mathrm{fg} \pm 40.1$ & $188.7 \mathrm{e} \pm 17.9$ & $36.3 \mathrm{~d} \pm 7.4$ \\
\hline & Summer & $455.7 b c \pm 36.2$ & 137.2 cde \pm 15.9 & $69.8 b c \pm 15.2$ & 682.4 de \pm 37.2 & $568.1 b \pm 17.2$ & $110.2 \mathrm{abc} \pm 22.1$ \\
\hline & Autumn & $233.2 \mathrm{de} \pm 36.8$ & $69.3 \mathrm{de} \pm 7.6$ & 42.7 cde \pm 1.7 & $515 \mathrm{fg} \pm 40.1$ & $188.7 e \pm 17.9$ & $36.3 \mathrm{~d} \pm 7.4$ \\
\hline
\end{tabular}




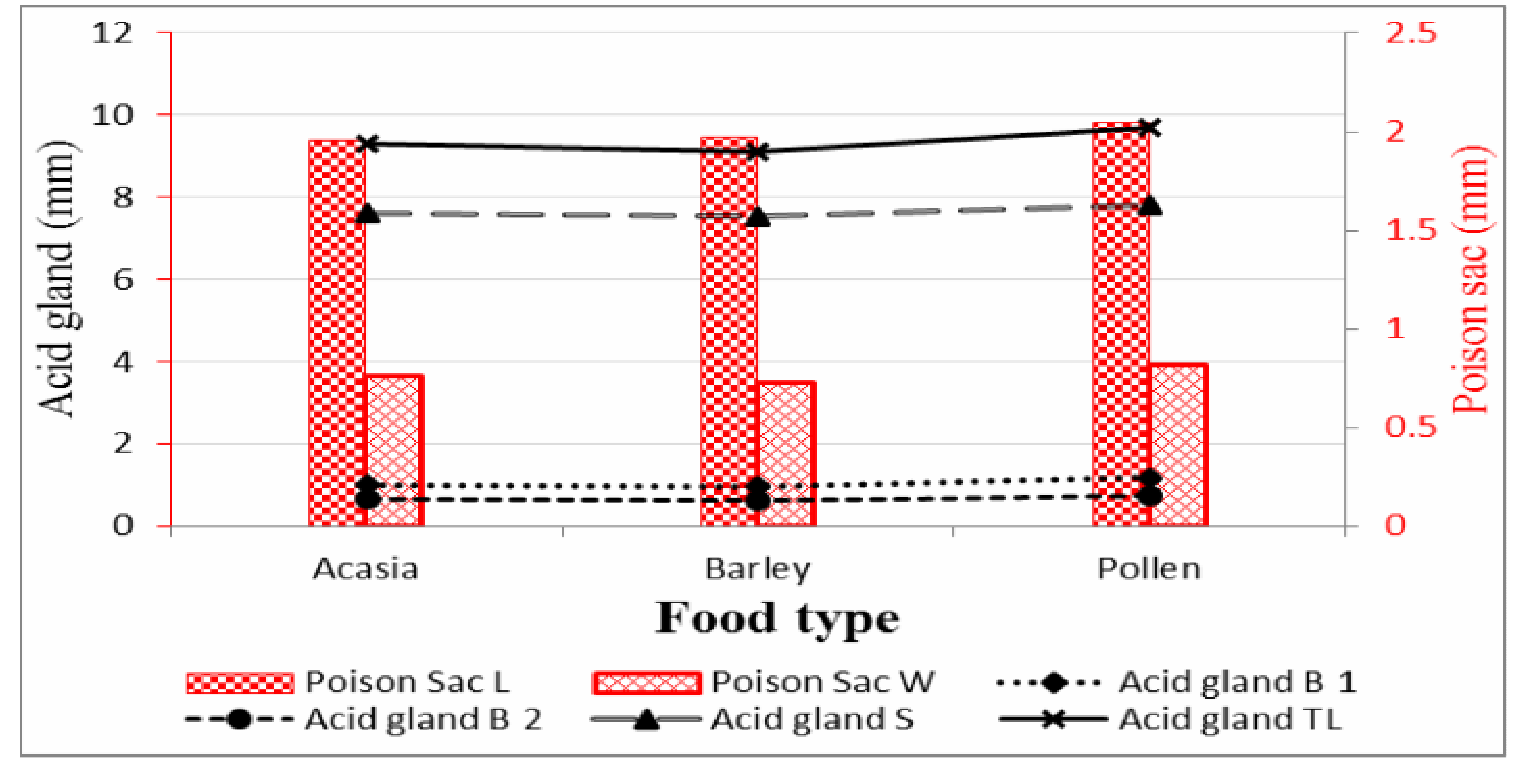

Acid gland $\quad \mathrm{B} 1=$ Branch $1 \quad \mathrm{~B} 2=$ Branch $2 \quad \mathrm{~S}=$ Stalk $\quad \mathrm{TL}=$ Total Length Poison Sac $\mathrm{L}=$ Length Poison Sac W=Width

Fig. 1: Biometrical measurements of poison sac and acid gland according to food diets offered to honey bee workers (mean \pm SD).

\section{Conclusion}

It could be concluded that feeding honeybee on acacia, barley and pollen increase all activates of honeybee colonies such as worker's sealed brood area and the produced venom amounts.

\section{REFERENCES}

Ali, M.A.M. (2012). Studies on bee venom and its medical uses. Int. J. Adv. Res. Tech., 1 (2): 1-15.

Aly, M.Z.; Osman, K.S.; Mohanny K. and Elsayeh, W.A. (2014). New formula of pollen supplemental diets to study honey bee (apis mellifera carnica) attractiveness. Egypt. Acad. J. Biolog. Sci., 7(2): 47-55.

Bogdano, V.S. (2016). Bee Venom: production, composition and quality. In: The bee venom Book, Chapter 1, Muehlethurnen, Switzerland. www.beehexagon.net.
El-Shaarawy, K.O.; M.E. Zakaria; Azza Taufik, A. and A.A.M. El-Shemy (2007). Effect of different bee venom collection periods using electrical shock device on some venom characteristics and honey bee colony activities. J. Agric. Sci., Mansoura Univ., 32 (6): 4769- 4775.

Haggag, S.I.; Abed Al-Fattah, M.A.; Ewies, M.A. and El-Feel, M.A. (2015). Effect of honeybee venom collection from different races on honey area. Aca. J. Entom., 8 (4):190-192.

Hayes, J.V. (1984). Supplemental feeding of honey bees. Ame. Bee J., 1: 35-37.

Lauter, W.M. and Vrla (1939). Factors influencing the formation of the venom of the honey bee J. Econ. Entomol., 32: 506-807.

Nowar, E.E. (2016). Venom Glands Parameters, Venom Production and Composition of Honeybee Apis mellifera L. Affected by Substitute Feeding. Mid. East J. Agric. Res., 5 (4): 596-603. 
Rashid, M.; Elizabeth Wagchoure, S. and

Sarwar, G. (2013). Influence of supplemental diets on Apis mellifera L. Colonies for honey production, Pak. J. Agric. Res., 26 (4).

Roat, T.C.R.; Nocelli, C.F. and Cruz-landim, C. (2006a). Ultrastrural modifications in the venom glands of workers of Apis mellifera L. (Hymenoptera: Apidae) Promoted by topical application of juvenile hormone. Neotrop. Entomol., 35: 469-476.

SAS Institute Inc. (2004). SAS procedures Guide for personal Computers,
Statistical Analysis System Institute, Inc., Cary, N.C.

Snedecor, G.W. and Cochran, W.G. (1972). Statistical method 6 The Lowa State Univ. press, Ames, lowa USA, 59.

Szymas, B. and Przybyl, A. (1995). Zastosowanie bialka ziemniaka wzywieniu paszcoly miodnej (Apis mellifera L.).

Zakaria, M.E. and Mohammed, A.Z. (2004). Protein electrophoretic changes of haemolymap and venom of honey bee workers (apis melliera) L. fed different protein diets., Bull. Ent. Soc. Egypt, 30: 43-55.

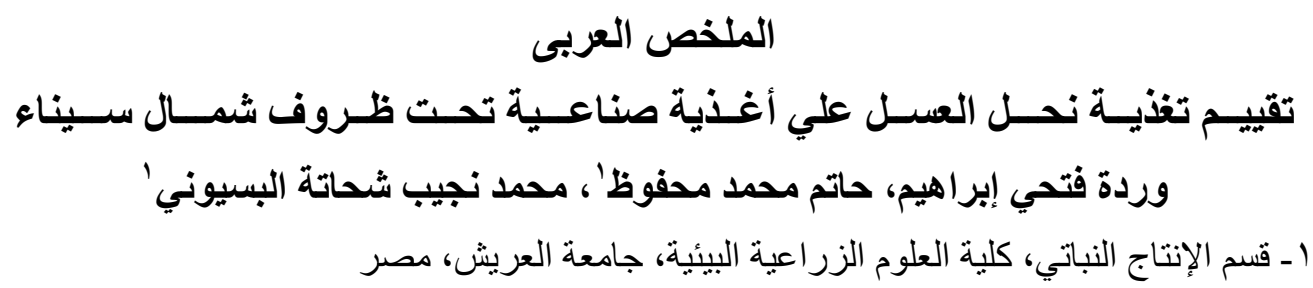

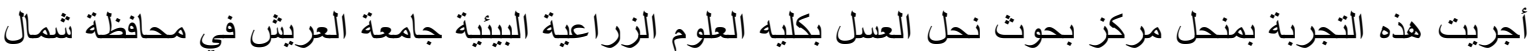

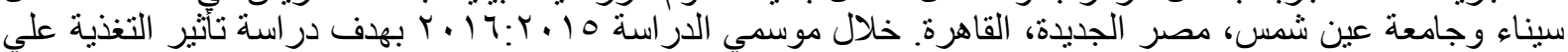

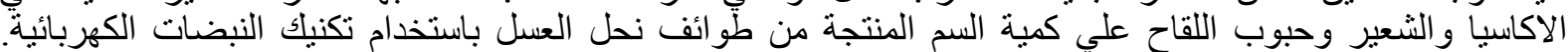

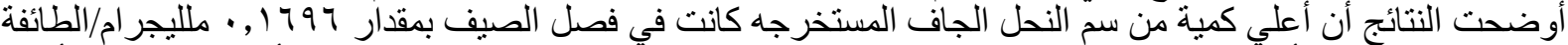

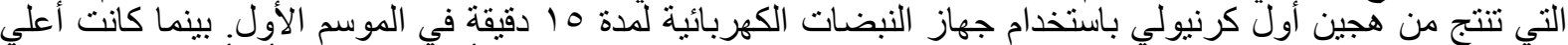

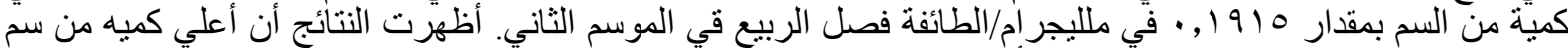

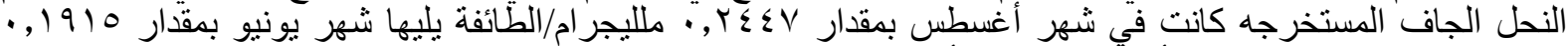

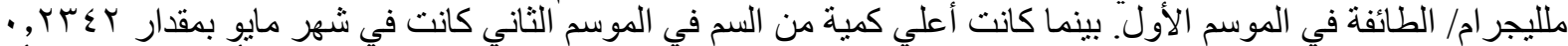

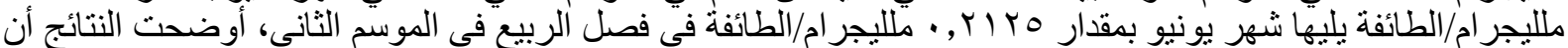

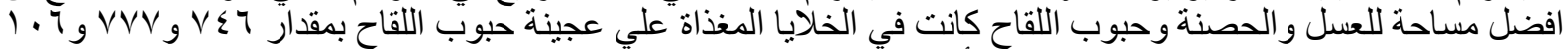

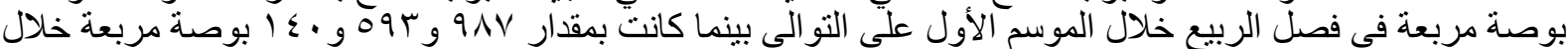

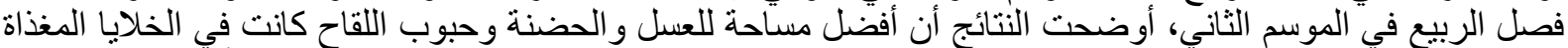

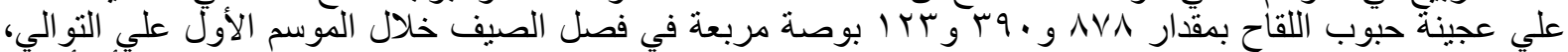

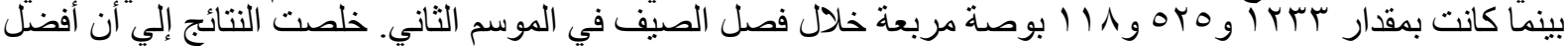

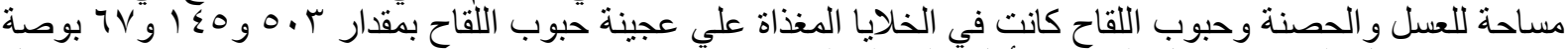

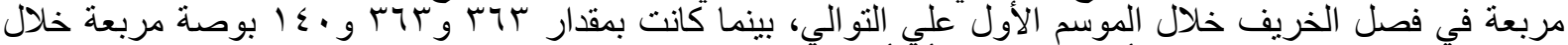

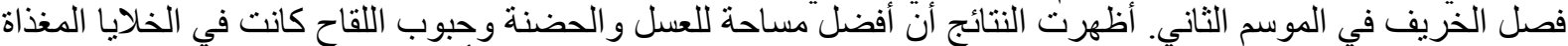

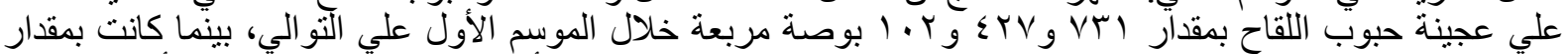

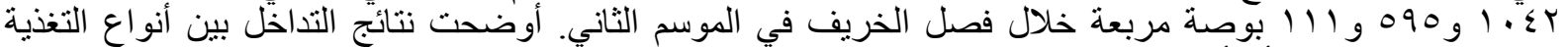

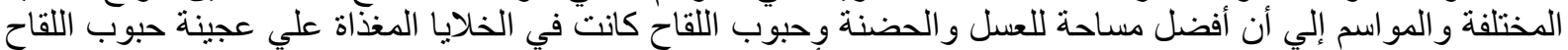

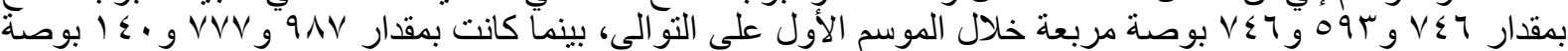

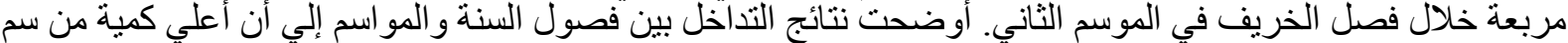

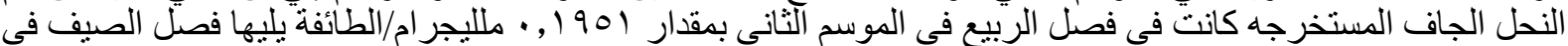

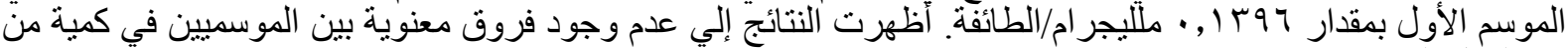

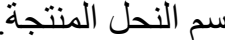
الكلمات الإسترشادية: تغذية، نحل العل، أغذية صناعية. 